\title{
Guillain, Barraquer and I
}

\author{
Guillain, Barraquer e eu \\ Mario Emílio Dourado?
}

\begin{abstract}
The year 2016 was the centennial anniversary of the recognition of the Guillain-Barré syndrome, which was first described by George Guillain, Jean-Alexandre Barré and André Strohl. In celebration of the centennial, this historical review describes aspects of the contributions of Guillain and the Spanish neurologist, Barraquer-Bordas and a brief account of the Fourth International Neurological Congress, which brought together Guillain and Barraquer-Bordas. There were many outstanding Brazilian physicians at that meeting. Finally, the author describes his interaction with Barraquer-Bordas and provides an account of his influence in shaping a generation of Brazilian neurologists, including himself.
\end{abstract}

Keywords: history of medicine; autoimmune diseases of the nervous system; Guillain-Barré syndrome; polyradiculoneuropathy; Zika virus infection.

\section{RESUMO}

O ano de 2016 foi o aniversário do centenário do reconhecimento da síndrome de Guillain-Barré (GBS), que foi descrita pela primeira vez por George Guillain, Jean-Alexandre Barré e André Strohl. Em comemoração ao centenário, esta revisão histórica descreve aspectos das contribuições de Guillain e Barraquer-Bordas e uma breve descrição do IV Congresso Neurológico Internacional, que reuniu Guillain e o neurologista espanhol Barraquer-Bordas. Naquela reunião houve participação também de excelentes médicos brasileiros. Finalmente, o autor descreve sua interação com Barraquer-Bordas e fornece uma descrição de sua influência na formação de uma geração de neurologistas brasileiros, incluindo ele próprio.

Palavras-chave: história da medicina; doenças autoimunes do sistema nervoso; síndrome de Guillain-Barré; polirradiculoneuropatia; infecção pelo Zika virus.

I have had the privilege of meeting a gentleman who had shaken hands with Guillain. The Guillain to whom I am alluding is Georges Charles Guillain (1876-1961) who, along with Jean Alexandre Barré (1880-1967) and Andre Strohl (1887-1977) reported, at a meeting in Paris, on two clinical cases of young soldiers, who had returned from the First World War having recovered from flaccid, ascending paralysis in 1916, exactly 101 years ago. The physicians reported the presence of areflexia and increased protein in the cerebrospinal fluid (CSF), without an increase in the CSF cell count. The dissociation between albumin and cell count in the CSF was a crucial milestone, distinguishing this new syndrome from poliomyelitis, then the most common paralysis, and other diseases of the peripheral nervous system. ${ }^{1}$

The eponym, Guillain-Barré syndrome (GBS), was introduced in 1927 by Drăgănescu and Claudian at the Congress of the Neurology Society of Paris, which was led by Barré. The reasons why Strohl was omitted from the eponym are not clear. ${ }^{1}$. The eponym is still used worldwide for its clarity in describing GBS, making its diagnosis easy and accessible to the non-neurological community. Interestingly, Guillain maintained that a microorganism would eventually be found as the cause of the syndrome, as described for poliomyelitis. We now know that approximately two-thirds of patients with GBS report a previous infectious illness, most commonly diarrhea or a respiratory disease, or vaccination, days to weeks preceding the onset of neurologic signs ${ }^{2}$. The recent outbreak of Zika virus (ZIKV), in a naïve population in Latin America and, before that, in French Polynesia, further supports Guillain's original hypothesis of an infectious etiology for triggering the syndrome. Guillain-Barré syndrome is now considered an immune-mediated disorder; autoantibodies may form in response to a variety of antigenic stimuli, either of bacterial or viral origins. This appears to be the mechanism induced by Campylobacter jejuni in the axonal subtype of GBS. The mechanism of the demyelinating variant associated with viral infections is still not understood, but probably is also in part immune-mediated ${ }^{2}$.

Luís Barraquer-Bordas or Lluís Barraquer III (1923-2010) was one of the most influential Catalan neurologists. He was an honorary member of medical societies around the world, 
including the Brazilian Academy of Neurology. His grandfather was Lluís Barraquer-Roviralta, founder of the first nucleus of clinical neurology in Spain in 1882, whereas his father, Lluís Barraquer-Ferré, was the first president of the Sociedad Española de Neurología $a^{3,4}$.

In September 1949, at age 26, Lluís Barraquer-Bordas attended the Fourth International Neurological Congress in Paris, along with his father. During the meeting, Barraquer was introduced to Guillain, and they shook hands and discussed various medical topics. Théophile Alajouanine was the President and Raymond Garcin was the Secretary-General. The four main topics selected for discussion were the thalamus and its pathology; electroencephalography and electromyography; viral diseases of the nervous system, and neurosurgery, especially cordotomy. In addition, surgery for the prevention of pain was also discussed. There were 1,440 participants at the meeting, medical and non-medical, from 46 different countries ${ }^{5,6}$. Among the Brazilian physicians were Deolindo Couto (the founding director of the Institute of Neurology of the University of Brazil), Aloysio de Castro (the pioneer of neurosemiology in Brazil), Oswaldo Freitas-Julião (the founder of the Neurology Core of São Paulo, a leprosy scholar), Oliveira Dias Thales (a pioneer in the Department of Psychiatry and Medicine at the Federal University of Rio de Janeiro, where he was professor of Legal Medicine), Waldemar Berardinelli (the founding President of the Brazilian Society of Rheumatology, who later described the Berardinelli-Seip syndrome), and Éser Americano da Costa (a urologist from Bahia) $)^{5}$. During the congress, Alfonso Asenjo, from Chile, arranged for a meeting of a group of neurosurgeons who discussed how neurosurgery might present itself at international congresses in the future. In the end, they decided to start a new society ${ }^{5}$.

During his illustrious career, Barraquer published more than 400 papers, including the book "Fundamentals of Neurology" in 1963, with a preface by Raymond Garcin 3 . Barraquer maintained contact with Guillain, even after Guillain's retirement, when he continued to be honorary president of the Neurology meeting and an active participant.

Barraquer built several political and scientific relationships in Brazil. He admired Dom Helder Câmara, the bishop of Olinda. Barraquer was interested in religion and was critical of conservative aspects of the Catholic Church. He visited several cities in Brazil, including Natal. His first visit was to attend the Rehabilitation Congress in Fortaleza. He recalled the Pelourinho in Salvador and had great memories of Rio de Janeiro, especially of having watched a soccer match at the Maracanã stadium; not any match, but a match in which Pelé played. He also remembered that some colleagues had warned him, while he was in Rio, to keep his watch in his pocket and not to stop at traffic lights; unfortunately a situation which currently has worsened. He visited Recife at the invitation of Dr. Quiapeta and participated in a North-Northeast Congress of Neurology. He was not allowed to talk to Dom Helder Câmara, due to censorship by the militaries that prohibited
Bishop Câmara from interacting with any foreigners. He fondly recalled Dr. Oswaldo Freitas Julião, a leprosy scholar.

Robert Wartenberg (1887-1956), Barraquer's friend and author of one of the most important pioneering books "The Examination of Reflex: A Simplification", suggested that Barraquer-Bordas prepare a tribute to his father, Barraquer-Ferré. This tribute was published in 1952, in two supplements of the Archives of Neuropsychiatry, which were made available by Dr. Lange. ${ }^{8}$ The two articles were written in collaboration with the world's neurology elite. I asked him why he had not published it in Spain, and Professor BarraquerBordas replied that, at the time, internists and psychiatrists did not acknowledge a chair of neurology in Spain.

I graduated in Medicine from the Federal University of Rio Grande do Norte, in Natal, Brazil, in 1987, then traveled to Barcelona for training in Neurology and Neuromuscular disorders (1988-1993) at the Hospital Santa Creu i Sant Pau. Professor Barraquer-Bordas was retired by then, but attended the Neurology Service weekly, and I had the privilege of interacting with him. My supervisors were Josep Maria Grau Veciana, Jesus Pradas Orozco, Isabel Illa Sendra, Josep Lluís Martí Vilalta (in memoriam), Antonio Escartín Siquier, Carles Roig Arnall, Jaume Kulisevsky and Joan Martí Fábregas. The choice of Barcelona for many young physicians interested in Neurology was inspired by our own neurologist, Fabio Melo dos Santos, who, 10 years before, had made the same journey. A year after my arrival in Barcelona, I enjoyed the company of Marcos Lima de Freitas, another physician from Natal. Others came later.

After I returned to Brazil, I worked for many years in the main emergency public hospital in Natal (Hospital Monsenhor Walfredo Gurgel). I had the opportunity to diagnose and monitor hundreds of cases of GBS in both children and adults. Little by little, I gathered data that later enabled me to publish the epidemiology of GBS in Rio Grande do Norte9. Historically, GBS epidemics had been described elsewhere, as in China, but not in Brazil, until the recent outbreaks of ZIKV and Chikungunya virus infections.

We documented an outbreak of GBS in Natal between April-May 2015 (personal unpublished data). In the majority of cases the onset of neurological involvement occurred within days of the onset of symptoms and findings characteristic of ZIKV infection ${ }^{10}$. The outbreak of ZIKV was also associated with microcephaly in newborns infected in uter ${ }^{11}$. The ZIKV outbreak drew attention to the need for the medical community be aware of GBS. In the majority of patients, the treatment of GBS requires an intensive care unit, which is not available in many rural communities.

Professor Barraquer-Bordas described his meeting with Guillain in 1946 (Figure 1), in a letter to me in January 2006. The last time I personally met with Barraquer-Bordas was in 2008, on a visit to Barcelona (Figure 2). We talked about the importance of his book for the training of neurologists in Latin America. He was proud to learn that in Argentina, according to Dr. Marcelo Berth, all neurology residents read his book, entitled "Fundamental Neurology". 


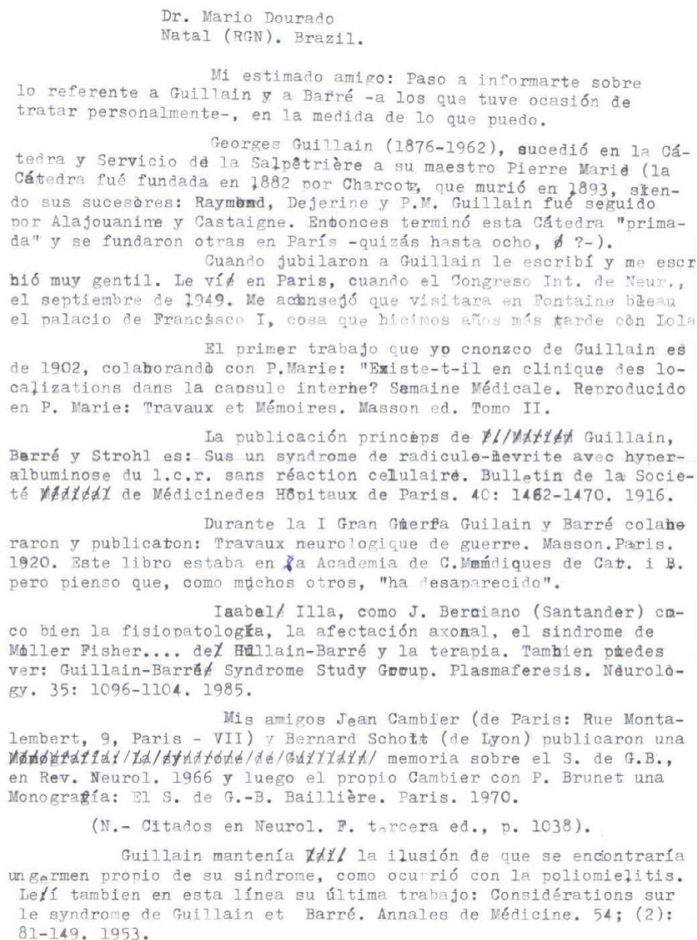

Figure 1. Letter from Prof. Lluís Barraquer-Bordas to Mário Emílio Dourado on January 15, 2006.

Finally, we have a great deal to celebrate on the centennial anniversary of the description of the GBS. The introduction of therapies such as plasmapheresis, intravenous human immunoglobulins, ventilator support, and rehabilitation have substantially improved survival and recovery. It is very gratifying to treat patients with GBS and observe their outcomes. I feel honored to have met Professor Lluís Barraquer-Bordas during my training and, through him, learn of his interactions with Georges Charles Guillain. Thanks to Professor Barraquer-Bordas and his handshake, I came to know the illustrious Professor Guillain.

\section{ACKNOWLEDGEMENTS}

The author wish to thank Selma Jeronimo, MD, PhD, for his review of the manuscript.

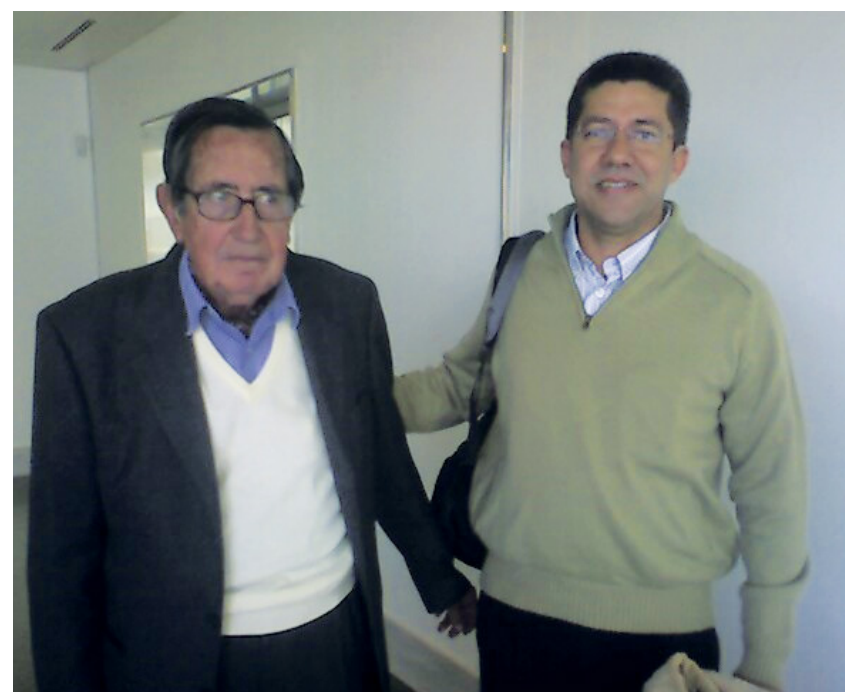

Figure 2. Lluís Barraquer-Bordas and Mário Emílio Dourado, at the Hospital Santa Creu i Sant Pau, Barcelona, 2008.

\section{References}

1. Pritchard J, Hughes RA. Guillain-Barré syndrome. Lancet. 2004;363(9427):2186-8. https://doi.org/10.1016/S0140-6736(04)16512-4

2. Willison $\mathrm{HJ}$, Jacobs BC, Doorn PA. Guillain-Barré syndrome. Lancet. 2016;388(10045):717-27. https://doi.org/10.1016/S0140-6736(16)00339-1

3. Sociedad Española de Neurologia. Exposición: Lluís Barraquer Bordas y la Sociedad Española de Neurología. Barcelona: Sociedad
Española de Neurologia; 2010 [cited 2016 Sep 16]. Available from: http://mah.sen.es/pdf/expo_2010.pdf

4. Rutz-Lara R. [Luis Barraquer Ferré].Arq Neuropsiquiatr. 1952;10(2):127-38 Spanish. https://doi.org/10.1590/S0004-282X1952000200003

5. Aarli JA. The history of the World Federation of Neurology: the first 50 years. Oxford: Oxford University Press; 2014.

6. Fourth International Neurological Congress. J Neurol Neurosurg Psychiatry. 1949;12(1):77. 
Maranhão-Filho P, Vincent MB, Silva MM. Neurological examination: pioneering authors and their books. Arq Neuropsiquiatr.

2015;73(2):140-6. https://doi.org/10.1590/0004-282X20140215

8. Lange O. Homenagem póstuma: Prof. Robert

Wartenberg. Arq Neuropsiquiatr. 1957;15(1):91-2.

https://doi.org/10.1590/S0004-282X1957000100010

9. Dourado ME, Félix RH, da Silva WK, Queiroz JW, Jeronimo SM. Clinical characteristics of Guillain-Barré syndrome in a tropical country: a Brazilian experience. Acta Neurol Scand. 2012;125(1):47-53. https://doi.org/10.1111/j.1600-0404.2011.01503.x

10. Araujo LM, Ferreira ML, Nascimento OJ. Guillain-Barré syndrome associated with the Zika virus outbreak in Brazil. Arq Neuropsiquiatr. 2016;74(3):253-5. https://doi.org/10.1590/0004-282X20160035

11. Heukelbach J, Alencar CH, Kelvin AA, Oliveira WK, Cavalcanti LPG. Zika virus outbreak in Brazil. J Infect Dev Ctries. 2016;10(2):116-20. https://doi.org/10.3855/jidc.8217 